\title{
Novel Schiff base copper complexes of quinoline-2 carboxaldehyde as proteasome inhibitors in human prostate cancer cells
}

Shreelekha Adsule ${ }^{1}$, Vivek Barve ${ }^{2}$, Di Chen ${ }^{3}$, Fakhara Ahmed ${ }^{1}$, Q Ping Dou ${ }^{3}$, Subhash Padhye $^{1,2}$, Fazlul H. Sarkar ${ }^{1}$

${ }^{1}$ Department of Pathology, Barbara Ann Karmanos Cancer Institute, Wayne State University, School of Medicine, 9374 Scott Hall, 540 E Canfield Avenue, Detroit, MI 48201

${ }^{2}$ Department of Chemistry, University of Pune, Pune 411007, India

${ }^{3}$ The Prevention Program, Barbara Ann Karmanos Cancer Institute, and Department of Pathology, School of Medicine, Wayne State University,

Detroit, Michigan, USA

Running title: Novel Schiff base copper complexes as proteasome inhibitors

\section{Supporting Information}

Contents of SI: Contains experimental details for the determination of biological activity, spectral data, and elemental analysis data for all new compounds.

\footnotetext{
To whom correspondence should be addressed: Phone 313-576-8327.Fax 313-576-8389. Email: fsarkar@med.wayne.edu, sbpadhye2003@yahoo.com

${ }^{2}$ Department of Chemistry, University of Pune, Pune 411007, India

${ }^{1}$ Department of Pathology, Barbara Ann Karmanos Cancer Institute, Wayne State University School of Medicine, 9374 Scott Hall, 540 E. Canfield Avenue, Detroit, MI 48201, USA
} 


\section{TABLE OF CONTENTS}

1. Instrumentation measurements

2. Chemistry: Synthesis of compounds 1 to 8 (FPA-136 to 143)

3. Biological experiments

4. Table 1: Analytical data of 1 to 8 (FPA-136 to 143)

5. Table 2: Infrared spectra of 1 to 8 (FPA-136 to 143) 


\section{Instrumentation}

Elemental analyses were carried out on Hosley $\mathrm{C} \mathrm{H} \mathrm{N}$ analyzer. IR spectra were recorded in nujol-mull in the range $4000-500 \mathrm{~cm}^{-1}$ on Shimadzu FTIR-8400 infrared spectrophotometer, while electronic spectra were recorded on a Spectronic Genesys-2 spectrophotometer using matched pair of $1 \mathrm{~cm}^{3}$ quartz cells in the range $250-1100 \mathrm{~nm}$. Conductivity of the metal complex was measured on a conductivity instrument EQ-664 from EQUIP-TRONICS. The instrument was calibrated by using $0.1 \mathrm{M} \mathrm{KCl}$ in the solvent prior to use. The EPR spectra of the compounds were recorded in DMSO at $77 \mathrm{~K}$ on a Varian X-band spectrometer. TCNE compound was used as a field marker. Magnetic susceptibilities of the metal complexes were measured at $298 \mathrm{~K}$ on a Faraday balance with the field strength of $7000 \mathrm{G}$ using $\mathrm{Hg}\left[\mathrm{Co}(\mathrm{SCN})_{4}\right]$. Cyclic voltammetric measurements were made in dimethylsulfoxide (DMSO) solvent on a BAS CV-27 instrument with an XY recorder using Pt disc as the working electrode against SCE and Pt wire as an auxiliary electrode with Tetraethyl ammonium perchlorate (TEAP) as the supporting electrolyte.

All reagents were of analytical-reagent (AR) grade and unless otherwise noted, all solvents, chemicals and reagents were obtained commercially and used without purification. Benzoyl hydrazide was prepared according to the method described in the literature ${ }^{1}$ and thiosemicarbazide hydrochloride was made following a procedure established in our laboratory. ${ }^{2}$ Solvents employed were purified by standard protocols prior to their use. ${ }^{3}$

\section{Experimental Methods Chemistry}

Synthesis of quinoline-2-carboxaldehyde Schiff bases (1, 3, 5 and 7)

The Schiff base ligands 1, 3,5 and 7 (Scheme 1) were synthesized by mixing equimolar amounts of quinoline-2 carboxaldehyde with thiosemicarbazide hydrochloride, benzoyl hydrazide, isonicotinoyl hydrazide and salicylic hydrazide, respectively, in methanolic solvent and maintaining the reaction mixture at reflux temperature for $1 \mathrm{hr}$. The products obtained were filtered off, recrystallized from (1:1) DMF-methanol and finally dried in vacuum desiccators over anhydrous $\mathrm{CaCl}_{2}$.

\section{Synthesis of copper complexes $(2,4,6$ and 8$)$}

The copper (II) complexes of $\mathbf{1}, \mathbf{3}, \mathbf{5}$ and $\mathbf{7}$ were synthesized by mixing equimolar amounts of the methanolic solutions of ligands and $\mathrm{CuCl}_{2} \cdot 2 \mathrm{H}_{2} \mathrm{O}$. The resulting mixture was refluxed at room temperature for $1 \mathrm{~h}$. The precipitates formed were removed by filtration, washed with the methanol solvent and dried in a vacuum over anhydrous $\mathrm{CaCl}_{2}$. The analytical elemental data for the copper complexes $(\mathbf{2}, \mathbf{4}, \mathbf{6}$ and 8) of quinoline-2carboxaldehyde are given in Table 1 under Supporting Information.

\section{Biology}

\section{Cell Culture}

Two cancer cell lines, PC-3 and LNCaP prostate cancer cell lines were chosen (American Type Cell Culture Collection, Manassas, VA). PC-3 and LNCaP were cultured in RPMI 1640 (Invitrogen, Carlsbad, CA) medium supplemented with 10\% fetal bovine serum and $1 \%$ penicillin and streptomycin in a $5 \% \mathrm{CO}_{2}$ atmosphere at $37^{\circ} \mathrm{C}$. 
Reagents for proteasome assay

Purified rabbit $20 \mathrm{~S}$ proteasome, fluorogenic proteasomal chymotrypsin-like peptide substrate Suc-Leu-Leu-Val-Tyr-AMC were obtained from Calbiochem Inc. (San Diego, CA). Another fluorogenic peptide substrate Z-Gly-Gly-Leu-AMC specific for the proteasomal chymotrypsin-like activity was from BIOMOL International LP (Plymouth Meeting, PA).

Cell growth inhibition assay by 3-(4, 5-dimethylthiazol-2-yl)-2, 5-diphenyltetrazolium bromide

Two cancer cell lines were seeded in 96-well culture plates. After 24 hours of incubation, PC-3 and LNCaP cells were treated with 1, 5, 10, 15, 20, $\mu \mathrm{M}$ of compounds 1 to 8 (FPA-136 to 143) for $72 \mathrm{~h}$. The number of viable cells remaining after an appropriate treatment was determined by the MTT assay. Briefly cells were plated (4,000 cells/well per $0.2 \mathrm{ml}$ RPMI 1640 medium) in 96-well micro titer plates and incubated overnight. The test compound was then added to each well at a fixed concentration in quadruplicate wells. After treatment, cells were incubated with 3-(4, 5-dimethylthiazol-2-yl)-2, 5-diphenyltetrazolium bromide (MTT; $0.5 \mathrm{mg} / \mathrm{mL}$, Sigma) at $37^{\circ} \mathrm{C}$ for 2 hours and then with isopropyl alcohol at room temperature for 1 hour. The spectroscopic absorbance of the samples was determined by ULTRA Multifunctional Microplate Reader (TECAN, Durham, NC) at $595 \mathrm{~nm}$ as described previously. ${ }^{4}$ For $\mathrm{IC}_{50}$ values, the mean and standard deviation (SD) of relative growth was graphed versus log concentration of compound. The $\mathrm{IC}_{50}$ was calculated by sigmoidal dose response curve using Prism software (GraphPad, San Diego, CA).

\section{Histone/DNA ELISA for detecting apoptosis}

Cell Apoptosis ELISA Detection Kit (Roche, Palo Alto, CA) was used to detect apoptosis according to the protocol supplied by the manufacturer. Briefly, PC-3 and LNCaP cells were treated with two concentrations (one at $\mathrm{IC}_{50}$ and the other above $\mathrm{IC}_{50}$ values) of the compounds 1 to 8. After treatment, the cytoplasmic histone / DNA fragments from cancer cells with different treatments were extracted and bound to immobilized anti-histone antibody. Subsequently, the peroxidase-conjugated anti-DNA antibody was used for the detection of immobilized histone/DNA fragments. After addition of substrate for peroxidase, the spectrophotometric absorbance of the samples was determined by ULTRA Multifunctional Microplate Reader (TECAN) at $405 \mathrm{~nm}$ as described previously. ${ }^{4}$

\section{Western blot analysis}

Cell lysates $(50 \mu \mathrm{g})$ were subject to SDS-PAGE and then transferred to a nitrocellulose membrane, followed by incubation with primary antibodies and subsequently with secondary antibodies and the signal was visualized via the enhanced chemiluminescence (ECL) kit (Amersham Biosciences). The ECL Western blot analysis was also performed using specific antibodies to ubiquitin and PARP as described previously. ${ }^{4}$ Proteasome inhibition was measured as accumulation of ubiquitinated proteins and PARP cleavage which served as a marker for apoptosis.

\section{In vitro proteasome activity assays}

The chymotrypsin-like activity of proteasome was measured as previously described.

${ }^{5}$ Briefly, purified $20 \mathrm{~S}$ rabbit proteasome $(0.1 \mu \mathrm{g})$ or human prostate cancer LNCaP cell extract $(10 \mu \mathrm{g})$ was incubated in $100 \mu \mathrm{l}$ of assay buffer $(50 \mathrm{mmol} / \mathrm{L}$ Tris- $\mathrm{HCl}, \mathrm{pH} 7.5)$, with or 
without different concentrations of each tested reagent and $20 \mu \mathrm{mol} / \mathrm{L}$ fluorogenic peptide substrate Suc-Leu-Leu-Val-Tyr-AMC (for the proteasomal chymotrypsin-like activity), for 2 $\mathrm{h}$ at $37^{\circ} \mathrm{C}$. After incubation, production of hydrolyzed AMC groups was measured using a Wallac Victor $3^{\mathrm{TM}}$ multilabel counter with an excitation filter of $355 \mathrm{~nm}$ and an emission filter of $460 \mathrm{~nm}$.

Inhibition of the proteasome activity in intact tumor cells

To measure the inhibition of proteasome activity in living tumor cells, $100 \mu \mathrm{l}$ of LNCaP $\left(1 \times 10^{4}\right.$ cells/well $)$ cells were cultured in a 96-well plate. These cells were treated with or without various concentrations of tested reagents for $18 \mathrm{~h}$, followed by an additional incubation for $2 \mathrm{hr}$ with the fluorogenic peptide substrate Z-Gly-Gly-Leu-AMC specific for the proteasomal chymotrypsin-like activity. Afterwards, production of hydrolyzed AMC groups was measured using the same plate reader and conditions mentioned above.

\section{Hydrogen Peroxide $\left(\mathrm{H}_{2} \mathrm{O}_{2}\right)$ detection}

$\mathrm{LNCaP}$ cells were treated with two concentrations $\left(\mathrm{IC}_{50}\right.$ and one above $\mathrm{IC}_{50}$ ) of $\mathrm{Cu}$ alone, 1, solution mixture of $\mathbf{1}$ and $\mathrm{CuCl}_{2}$ and $\mathbf{2}$ for upto $24 \mathrm{hr}$, followed by assaying the presence of $\mathrm{H}_{2} \mathrm{O}_{2}$ using Amplex ${ }^{\circledR}$ Red Hydrogen Peroxide Kit (Molecular Probes) in accordance with the manufacturer's directions.

\section{References:}

1. Furniss, B.; Hannaford, A.; Smith, P.; Tatchell, A. Vogel's Text-book of Practical Organic chemistry. $5^{\text {th }}$ Edition, ELBS: Longman, UK, 1989.

2. Afrasiabi, Z.; Sinn, E.; Padhye, S. B.; Dutta, S.; Padhye, S.; Newton, C.; Anson, C. E.; Powell, A. K. J. Phenanthraquninoe thiosemicarbazone and its transition metal complexes with potential anticancer activity: Synthesis, structure, spectral properties and in vitro anticancer activity against human breast cancer cell line T47D. J.Inorg Biochem. 2003, 95, 306-314.

3. Perrin, D. D.; Armarego, W. L. F.; Purification of Laboratory Chemicals, $3^{\text {rd }}$ Ed (Pergamon Press, New York, 1988).

4. Banerjee, S.; Zhang, Y.; Ali, S.; Bhuiyan, M.; Wang, Z.; Chaio, P.J.; Philip, P.A.; Abbruzzese, J.; Sarkar, F.H.; Molecular Evidence for Increased Antitumor Activity of Gemcitabine by Genistein In vitro and In vivo Using an Orthotopic Model of Pancreatic Cancer. Cancer Research. 2005, 65, 9064-9072.

5. Daniel, K.G.; Chen, D.; Harbach, R.H.; Guida, W.C.; Dou, Q.P.; Organic copper complexes as a new class of proteasome inhibitors and apoptosis inducers in human cancer cells. Biochem Pharmacol, 2004, 67, 1139-1151. 
Table 1

\begin{tabular}{|c|c|c|c|c|c|c|c|c|c|c|}
\hline \multirow[t]{2}{*}{ Compound } & \multicolumn{5}{|c|}{ Elemental Analysis } & \multirow{2}{*}{\begin{tabular}{|l|}
$\mu$ \\
eff. \\
$B M$
\end{tabular}} & \multirow{2}{*}{\begin{tabular}{|l} 
EPR \\
g/l \\
$\mathrm{g} \perp$ \\
(gauss)
\end{tabular}} & \multirow{2}{*}{\begin{tabular}{|l|}
$\Lambda \mathrm{M}$ \\
$\mathrm{Ohm}-\mathrm{l}$ \\
$\mathrm{cm} 2$ \\
$\mathrm{~mol}-\mathrm{l}$
\end{tabular}} & \multirow{2}{*}{$\begin{array}{l}\text { UV- } \\
\text { Vis } \\
(\mathbf{n m}) \mathbf{b}\end{array}$} & \multirow{2}{*}{$\begin{array}{l}\text { E1/2 } \\
(\mathrm{V})\end{array}$} \\
\hline & $\% \mathrm{C}$ & $\% \mathrm{H}$ & $\% \mathrm{~N}$ & $\% \mathrm{~S}$ & M\% & & & & & \\
\hline 1 (FPA 136) & \begin{tabular}{|l}
57.37 \\
$(57.49)$
\end{tabular} & $\begin{array}{l}4.38 \\
(4.54)\end{array}$ & $\begin{array}{l}24.33 \\
(23.92)\end{array}$ & $\begin{array}{l}13.92 \\
(12.95)\end{array}$ & & - & 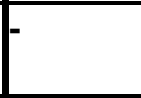 & |- & 305,320 & - \\
\hline 3 (FPA 138) & \begin{tabular}{|l}
74.17 \\
$(74.13)$
\end{tabular} & $\begin{array}{l}.76 \\
(4.86) \\
\end{array}$ & $\begin{array}{l}15.26 \\
(14.73)\end{array}$ & & - & - & |- & - & $\mathbf{3 1 0 , 3 3 0}$ & - \\
\hline 5(FPA 140) & $\begin{array}{l}\begin{array}{l}69.55 \\
(68.33)\end{array} \\
\end{array}$ & $\begin{array}{l}.38 \\
(4.76) \\
\end{array}$ & \begin{tabular}{|l|}
20.28 \\
$(19.63)$
\end{tabular} & & - & 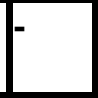 & |- & |- & 308,325 & - \\
\hline 7 (FPA 142) & $\begin{array}{l}70.09 \\
(69.63) \\
\end{array}$ & $\begin{array}{l}4.50 \\
(4.37) \\
\end{array}$ & $\begin{array}{l}14.42 \\
(13.83) \\
\end{array}$ & & - & - & $\mathbb{E}$ & |- & 320 & - \\
\hline 2 (FPA 137 & $\begin{array}{l}36.26 \\
(36.54)\end{array}$ & $\begin{array}{l}2.74 \\
(2.45)\end{array}$ & $\begin{array}{l}15.38 \\
(14.91)\end{array}$ & $\begin{array}{l}17.44 \\
(16.93)\end{array}$ & $\begin{array}{l}13.91 \\
(13.71) \\
\end{array}$ & 1.65 & 2.28 & 31 & $\begin{array}{l}300,325 \\
450,625\end{array}$ & $\begin{array}{l}+0.37 \\
\mathrm{r}\end{array}$ \\
\hline 4 (FPA 139) & $\begin{array}{l}49.87 \\
(48.95)\end{array}$ & $\begin{array}{l}3.17 \\
(2.94)\end{array}$ & $\begin{array}{l}10.26 \\
(9.45)\end{array}$ & & $\begin{array}{l}15.52 \\
(14.83)\end{array}$ & 1.68 & $\mid$\begin{tabular}{|l|}
2.29 \\
2.08
\end{tabular} & 28 & $\begin{array}{l}300,335 \\
410,640\end{array}$ & $\begin{array}{l}+0.36 \\
\mathrm{r}\end{array}$ \\
\hline 6(FPA 141) & $\begin{array}{l}46.82 \\
(45.90)\end{array}$ & $\begin{array}{l}2.92 \\
(2.51)\end{array}$ & $\begin{array}{l}13.65 \\
(12.91)\end{array}$ & & $\begin{array}{l}15.48 \\
(14.93)\end{array}$ & 1.70 & \begin{tabular}{|l}
2.30 \\
2.11
\end{tabular} & 22 & \begin{tabular}{|l}
300,330 \\
420,635 \\
\end{tabular} & $\begin{array}{l}+0.33 \\
\mathrm{r}\end{array}$ \\
\hline 8 (FPA 143) & \begin{tabular}{|l|}
48.00 \\
$(47.51)$
\end{tabular} & $\begin{array}{l}3.58 \\
(3.01)\end{array}$ & $\begin{array}{l}9.88 \\
(8.93)\end{array}$ & & $\begin{array}{l}14.94 \\
(14.45)\end{array}$ & 1.68 & $\begin{array}{l}2.29 \\
2.08\end{array}$ & 29 & $\mathbf{3 4 0 , 4 0 5 , 6 5 0}$ & $\begin{array}{l}+0.34 \\
\mathrm{r}\end{array}$ \\
\hline
\end{tabular}


Table 2

\begin{tabular}{|c|c|c|c|c|c|}
\hline Compound & $v(\mathrm{C}=\mathrm{O})$ & $\begin{array}{l}v(\mathrm{C}=\mathrm{O}) \\
\text { amide } \\
\mathrm{v}(\mathrm{C}=\mathrm{N})\end{array}$ & $\begin{array}{l}v(\mathrm{C}=\mathrm{N}) \\
\text { pyridine }\end{array}$ & $v(\mathrm{C}=\mathrm{S})$ & $v(\mathrm{NH})$ \\
\hline $\mathbf{I}$ & 1709 & - & F & - & $F$ \\
\hline 1 (FPA 136) & - & 1602 & 1583 & 1116 & 3273,3399 \\
\hline 3 (FPA 138) & $E$ & 1657 & 1558 & - & 3192,3395 \\
\hline 5(FPA 140) & - & 1663 & 1558 & - & 3188,3407 \\
\hline 7 (FPA 142) & $E$ & 1632 & 1547 & - & 3183,3385 \\
\hline 2 (FPA 137 & - & 1522 & 1450 & 1091 & 3265,3381 \\
\hline 4 (FPA 139) & $E$ & 1498 & 1431 & - & 3183,3381 \\
\hline 6(FPA 141) & $E$ & 1501 & 1417 & $E$ & 3175,3491 \\
\hline 8 (FPA 143) & 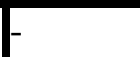 & 1500 & 1456 & 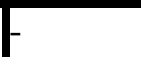 & 3172,3375 \\
\hline
\end{tabular}




\section{Figure 1}

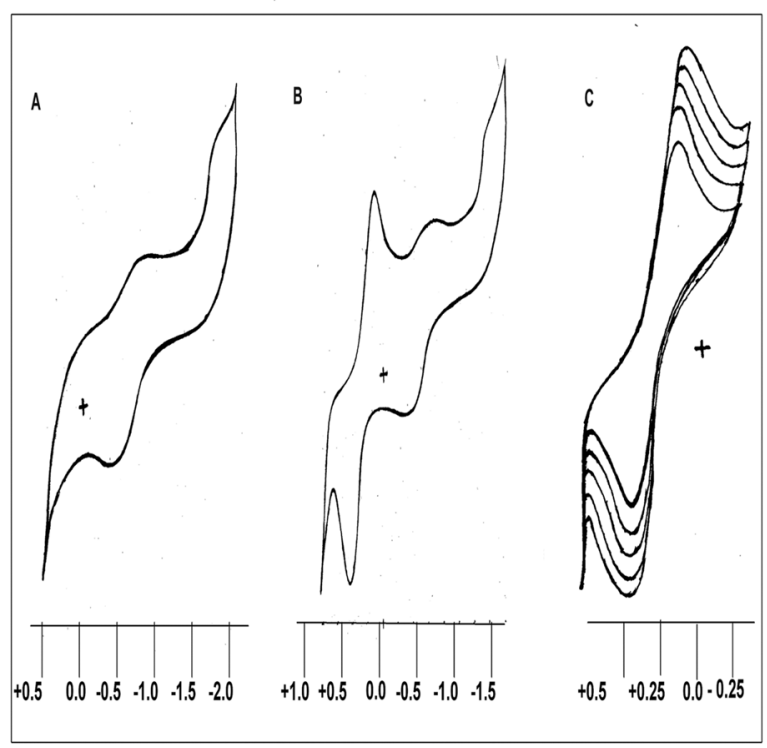

Figure 1: Cyclic voltammetry scan of (a) 1; (b) 2 and (c) scan rate dependence of 2.

\section{Figure 2}
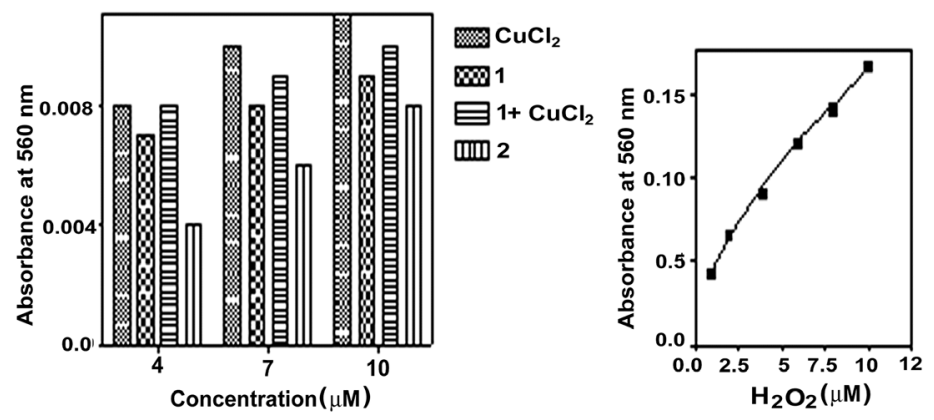

Figure 2: (A) Plot of absorbance at $506 \mathrm{~nm}$ indicating induction of $\mathrm{H}_{2} \mathrm{O}_{2}$ versus concentration of $\mathrm{Cu}$ alone, $\mathbf{1}$, mixture of $\mathbf{1}$ and $\mathrm{CuCl}_{2}$ and $\mathbf{2}(4,7$ and $10 \mu \mathrm{M})$, respectively. Treatment of LNCaP cells with $10 \mu \mathrm{M}$ copper complex 2 shows almost 2-fold lower absorbance (B) as compared to standard $\mathrm{H}_{2} \mathrm{O}_{2}$ curve where $10 \mu \mathrm{M}$ of $\mathrm{H}_{2} \mathrm{O}_{2}$ shows strong absorbance at $560 \mathrm{~nm}$ indicating high levels of $\mathrm{H}_{2} \mathrm{O}_{2}$ in $\mathrm{LNCaP}$ (untreated control) cells. 